\title{
New insights on Late Bronze Age Cu-metallurgy from Coles de Samuel hoard (Central Portugal): A combined multi-analytical approach
}

\author{
Carlo Bottaini ${ }^{\mathrm{a}, *}$, Raquel Vilaça ${ }^{\mathrm{b}}$, Nick Schiavon ${ }^{\mathrm{c}}$, José Mirão ${ }^{\mathrm{c}}$, António Candeias ${ }^{\mathrm{c}}$, Rui Bordalo ${ }^{\mathrm{d}}$, \\ Giovanni Paternoster ${ }^{\mathrm{e}}$, Ignacio Montero-Ruiz ${ }^{\mathrm{f}}$ \\ a CIDEHUS and HERCULES Laboratory, University of Evora, Largo do Marquês de Marialva, 8, 7000-809 Evora, Portugal \\ b Faculdade de Letras da Universdidade de Coimbra and Centro de Estudos em Arqueologia, Artes e Ciências do Património, 3004-530, Coimbra, Portugal \\ ${ }^{c}$ HERCULES Laboratory, University of Evora, Largo do Marquês de Marialva, 8, 7000-809 Evora, Portugal

 \\ Verdes, 37, 1300-001 Lisbon, Portugal \\ e Dept. of Physics "E. Pancini" - Naples University "Federico II and INFN Naples Div., via Cintia 80126 Italy \\ ${ }^{\mathrm{f}}$ Instituto de Historia-CSIC, Albasanz 26-28, 28037-Madrid, Spain
}

\section{A R T I C L E I N F O}

\section{Article history:}

Received 15 November 2015

Received in revised form 3 May 2016

Accepted 5 May 2016

Available online xxxx

\section{Keywords:}

Central Portugal

Late Bronze Age

Bronze alloys

Metal hoards

EDXRF

SEM-EDS

Optical microscopy

\begin{abstract}
A B S T R A C T
The hoard from Coles de Samuel is one of the largest Cu-based metal collections from the Late Bronze Age (LBA) (13th-8th centuries BC) ever found in Central Portugal, consisting of 18 artefacts which typologically display a strong regional identity. In the present study, an integrated multi-analytical approach combining Energy Dispersive X-Ray Fluorescence (EDXRF) analysis, Optical Microscopy (OM) and Scanning Electron Microscopy with Energy Dispersive X-ray spectroscopy (SEM-EDS) has been used to characterise the artefacts both from a chemical and microstructural point of view with the aim to unravel their elemental composition and technological features.

Results show that all artefacts are made of binary bronze (Cu-Sn) alloys, with a Sn content in the range of $8.7 \pm$ 0.9 and $13.0 \pm 1.0 \mathrm{wt} \%$, with minor elements ( $\mathrm{Pb}$, As and $\mathrm{Fe}$ ) never exceeding $1.1 \mathrm{wt} \%$ in total. The microstructure of the vast majority of the metal objects ( 13 out of 18 ) shows the presence of equiaxial $\alpha$-copper grains with annealing twins and slip bands suggesting that, in the manufacturing process, they were subjected to forging plus annealing cycles. The remains of the objects present an as-cast microstructure constituted by dendritic structures, suggesting that metals did not suffer any thermo-mechanical operation after being removed from the mould. $\mathrm{Pb}$, $\mathrm{Ag}$ and Au-rich globules together with $\mathrm{Cu}-\mathrm{S}$ and unalloyed $\mathrm{Cu}$-inclusions have been observed as well, resulting from impurities from ores.

The typological characterisation of these metals and their archaeometallurgical data are consistent with an indigenous LBA Iberian metallurgical production supporting the hypothesis of a regional/local production and use of the artefacts from Coles de Samuel.
\end{abstract}

(c) 2016 Elsevier Ltd. All rights reserved.

\section{Introduction}

\subsection{Archaeological context}

Hoarding objects is a common and cross-cultural human practice all throughout the European Prehistory (Hamon and Quilliec, 2008). In general terms, a hoard may be defined as a collection of one or more archaeological objects with distinct functional and typological characteristics, intentionally and selectively collected and either buried or deposited in underwater environment in specific sites in the absence of a clear archaeological context (Bottaini, 2013; Bradley, 1990; Delibes De Castro, 2007; Levy, 1981; Vilaça, 2006).

\footnotetext{
* Corresponding author.
}

The visual characteristics of the objects inside the hoards (typology, number and state of preservation) as well as the context where the items were deposited (wet or dry places, close to a settlement or a prominent element in the landscape, inside caves, mines, etc.) are the two main parameters traditionally taken into account for their classification and interpretation.

Based on these elements, a distinction is traditionally made between utilitarian (or non-ritual) and votive (or ritual) hoards: the former would reflect processes within the production and the circulation of metal and are usually considered as temporarily buried trade stocks (i.e. reserve of raw material or newly-made objects). The latter, linked to metal consumption, would be associated with the social position of the depositary and are considered ways of express wealth, status and ritual offerings to divinities or secular people. In contrast with the utilitarian hoards, the ritual ones are composed of objects with special 
symbolic values that would have been buried permanently, without the intention of being recovered (Taylor, 1993).

Since the first studies on hoards, in the second half of the 19th century, this bipolar classification - utilitarian vs. ritual hoards - has given rise to many interpretative problems and prolonged debates and discussions among researchers, proving that this approach is too paradigmatic and schematic to explain an archaeological evidence as complex as prehistoric hoards are: in fact, it is nowadays generally accepted that a hoard can no longer be viewed in terms of utilitarian or votive deposition and new and stimulating alternative perspectives have been adopted (Fontijn, 2002; Gosden and Marshall, 1999; Kopytoff, 1986; Osborne, 2004; Whitley, 2002; York, 2002).

Notwithstanding in the pre-industrial societies, technology does not correspond to a simply transformation of matter but it is embedded in social and cultural dynamics, the methodologies of physical, chemistry and material sciences can provide significant data for a more complete understanding of the hoarding phenomenon. To contribute to this scientific debate, the 18 artefacts from the Coles de Samuel collection were analysed by Energy Dispersive X-Ray Fluorescence (EDXRF) spectrometry to determine major and minor elements and thus provide their chemical composition and by Optical Microscopy (OM) and Scanning Electron Microscopy with Energy Dispersive X-ray spectroscopy (SEM-EDS) to characterise the microstructural features of the alloys and to reconstruct the technical chain of sequential operations by which natural resources were physically turned into cultural commodities (Dobres and Hoffman, 1994). Through the reconstruction of the technology applied in the production of these objects, the technological choices that ancient metalworkers did in the manufacturing of an object will be investigated.

More concretely, this paper seeks to: a) identify the chemical composition of the metals in order to compare the results with other data present in the literature; b) focus on the production technique used in the manufacturing of the metal artefacts; c) timeframe the results from Coles de Samuel collection within the LBA metallurgy from Western Iberia, in order to infer about metallurgical parallels.

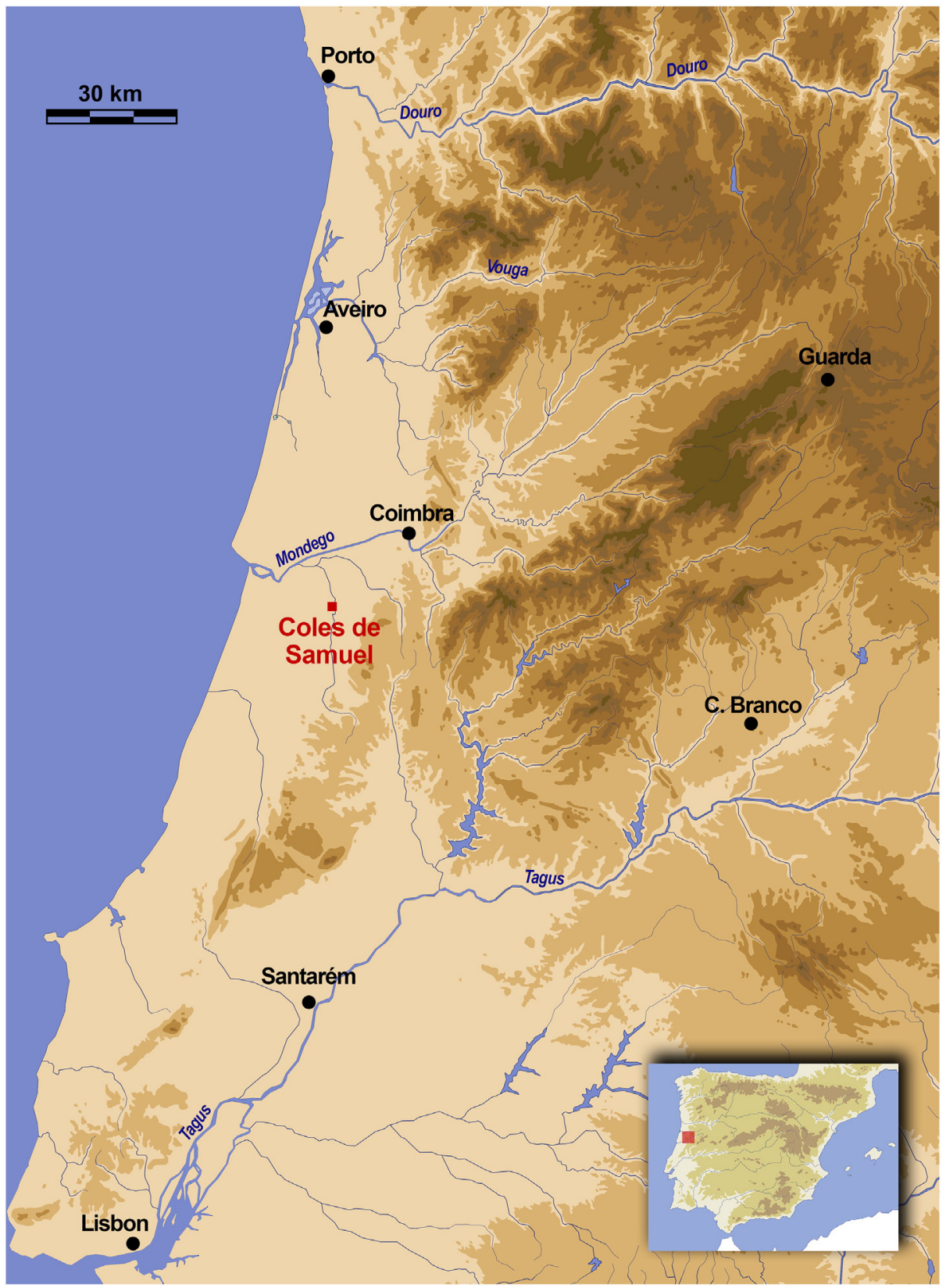

Fig. 1. Map of Central Portugal, with the location of the Coles de Samuel hoard. 

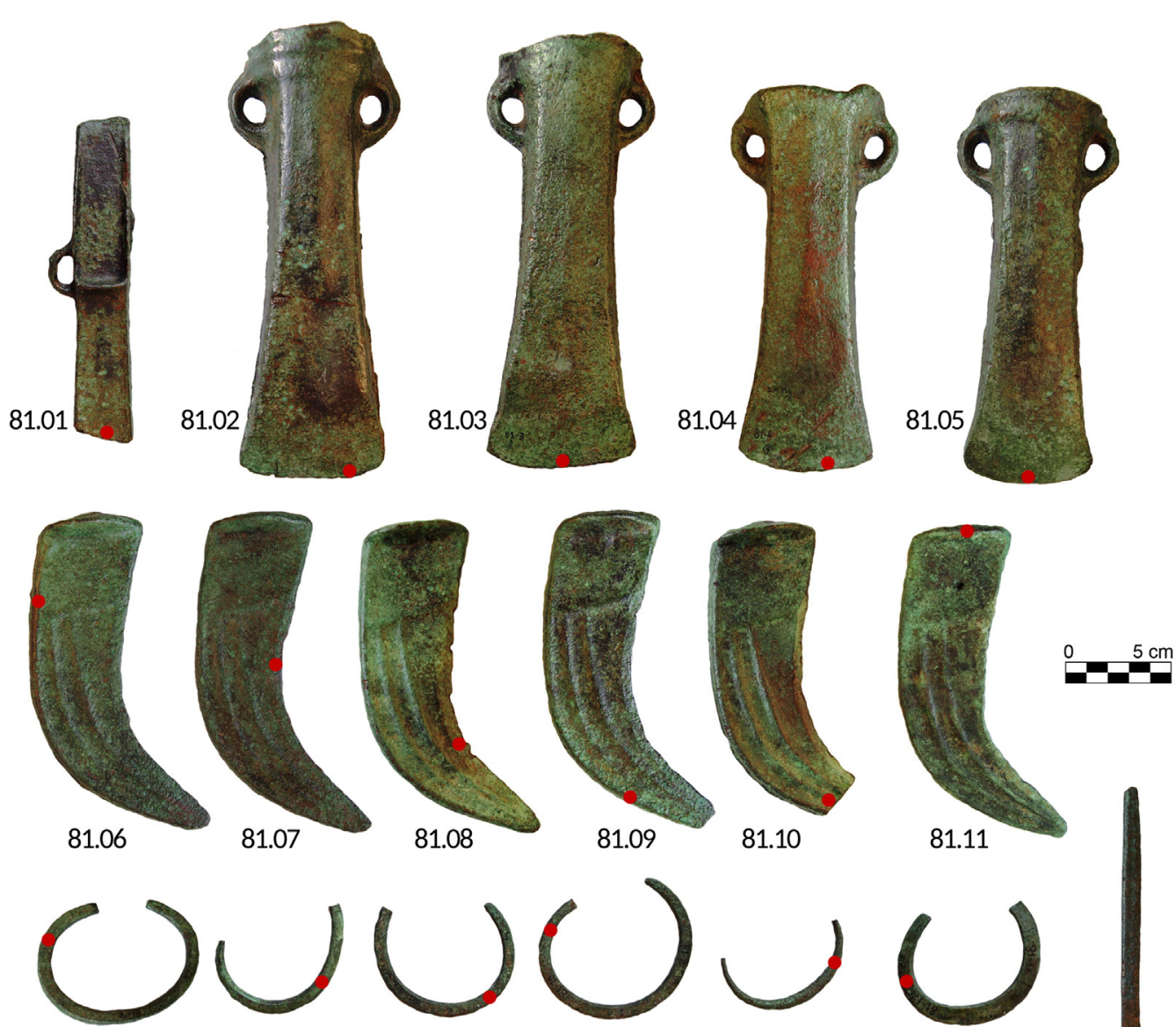

81.16

81.15

81.18

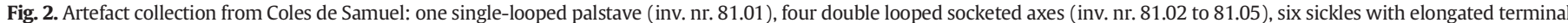

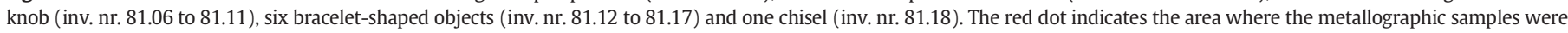
removed. (For interpretation of the references to color in this figure legend, the reader is referred to the web version of this article.)

\subsection{The Coles de Samuel hoard}

The selective and deliberate deposition of metals is a structuring feature of the Late Bronze Age (LBA) and Early Iron Age (EIA) (13th-8th century BC) in Central Portugal. In fact, single and multiple hoards, both mono- and multi-typological, composed by scraps, newly-made and used artefacts, buried in apparently expressionless places, close to stones, inside caves and mines, habitats or in wet places are widespread all over the region located between the Tagus and Douro rivers (Bottaini, 2013; Melo, 2000; Vilaça, 2006).

Within this scenario, Coles de Samuel can be considered as one of the largest multiple-object hoards from Central Portugal (Fig. 1), consisting of 18 artefacts: one single-looped palstave (inventory number 81.01), 4 double looped socketed axes (inv. nr. 81.02 to 81.05), six sickles with

Table 1

Results from XRF, OM and SEM-EDS; n.d.: not detected in the XRF analysis. The quoted errors are one standard deviation. C: Casting; A: Annealing; F: Forging; FF: Final Forging.

\begin{tabular}{|c|c|c|c|c|c|c|c|}
\hline Artefact & Inv. nr. & $\mathrm{Cu}(\mathrm{wt} \%)$ & Sn (wt\%) & $\mathrm{Pb}(\mathrm{wt} \%)$ & As (wt\%) & $\mathrm{Fe}(\mathrm{wt} \%)$ & Manufacture \\
\hline Palstave & 81.01 & $89.5 \pm 0.4$ & $10.0 \pm 1.0$ & n.d. & n.d. & $<0.05$ & $\mathrm{C}$ \\
\hline Socketed axe & 81.02 & $89.5 \pm 0.4$ & $10.2 \pm 1.0$ & $<0.2$ & $0.12 \pm 0.03$ & n.d. & $\mathrm{C}+(\mathrm{F}+\mathrm{A})+\mathrm{FF}$ \\
\hline Socketed axe & 81.03 & $90.0 \pm 0.4$ & $9.7 \pm 1.0$ & $0.28 \pm 0.06$ & n.d. & n.d. & $\mathrm{C}+(\mathrm{F}+\mathrm{A})+\mathrm{FF}$ \\
\hline Socketed axe & 81.04 & $88.5 \pm 0.4$ & $11.0 \pm 1.0$ & $0.22 \pm 0.07$ & $<0.08$ & n.d. & $\mathrm{C}+(\mathrm{F}+\mathrm{A})+\mathrm{FF}$ \\
\hline Socketed axe & 81.05 & $87.3 \pm 0.4$ & $12.0 \pm 1.0$ & $0.8 \pm 0.1$ & $0.29 \pm 0.05$ & n.d. & $\mathrm{C}+(\mathrm{F}+\mathrm{A})+\mathrm{FF}$ \\
\hline Sickle & 81.06 & $87.2 \pm 0.4$ & $13.0 \pm 1.0$ & $<0.2$ & $0.10 \pm 0.03$ & n.d. & $\mathrm{C}$ \\
\hline Sickle & 81.07 & $86.9 \pm 0.4$ & $13.0 \pm 1.0$ & $0.20 \pm 0.07$ & $<0.08$ & n.d. & $\mathrm{C}+(\mathrm{F}+\mathrm{A})+\mathrm{FF}$ \\
\hline Sickle & 81.08 & $91.3 \pm 0.5$ & $8.7 \pm 0.9$ & n.d. & n.d. & n.d. & $\mathrm{C}+(\mathrm{F}+\mathrm{A})+\mathrm{FF}$ \\
\hline Sickle & 81.09 & $87.5 \pm 0.4$ & $12.0 \pm 1.0$ & n.d. & $0.14 \pm 0.02$ & n.d. & $\mathrm{C}$ \\
\hline Sickle & 81.10 & $88.6 \pm 0.4$ & $11.0 \pm 1.0$ & $0.31 \pm 0.08$ & $0.12 \pm 0.03$ & n.d. & $\mathrm{C}$ \\
\hline Sickle & 81.11 & $86.7 \pm 0.5$ & $13.0 \pm 1.0$ & n.d. & $0.67 \pm 0.07$ & n.d. & $\mathrm{C}$ \\
\hline Bracelet shaped object & 81.12 & $87.1 \pm 0.4$ & $12.4 \pm 0.8$ & n.d. & $0.44 \pm 0.09$ & $0.06 \pm 0.02$ & $C+(F+A)$ \\
\hline Bracelet shaped object & 81.13 & $88.1 \pm 0.4$ & $11.6 \pm 0.7$ & n.d. & $0.31 \pm 0.07$ & n.d. & $C+(F+A)$ \\
\hline Bracelet shaped object & 81.14 & $88.5 \pm 0.4$ & $11.3 \pm 0.7$ & $0.16 \pm 0.04$ & n.d. & n.d. & $\mathrm{C}+(\mathrm{F}+\mathrm{A})+\mathrm{FF}$ \\
\hline Bracelet shaped object & 81.15 & $88.8 \pm 0.4$ & $11.1 \pm 0.7$ & $0.13 \pm 0.04$ & $<0.04$ & n.d. & $C+(F+A)$ \\
\hline Bracelet shaped object & 81.16 & $88.1 \pm 0.4$ & $11.8 \pm 0.7$ & n.d. & $0.08 \pm 0.02$ & n.d. & $C+(F+A)$ \\
\hline Bracelet shaped object & 81.17 & $88.2 \pm 0.4$ & $12.0 \pm 1.0$ & $0.25 \pm 0.06$ & n.d. & n.d. & $C+(F+A)$ \\
\hline Chisel & 81.18 & $86.7 \pm 0.4$ & $13.0 \pm 1.0$ & $0.34 \pm 0.06$ & n.d. & n.d. & $\mathrm{C}+(\mathrm{F}+\mathrm{A})+\mathrm{FF}$ \\
\hline
\end{tabular}




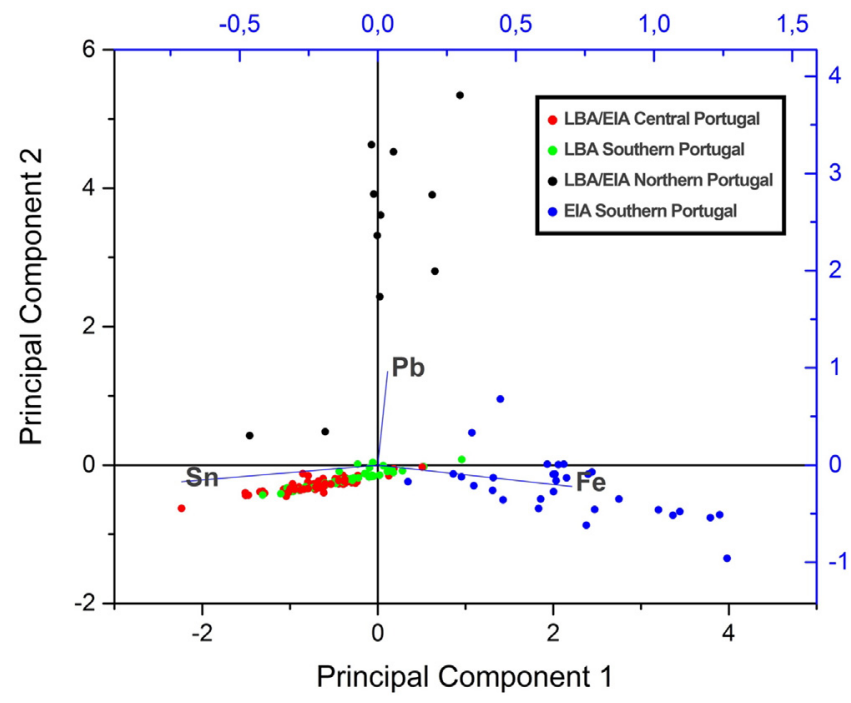

Fig. 3. Principal Component Analysis discriminating among the $\mathrm{Sn}$, Fe and $\mathrm{Pb}$ amount in Cu-based artefacts from Portuguese territory during LBA/ EIA. LBA/EIA Central Portugal: Freixianda (9 objects) (Gutiérrez Neira et al., 2011), Vila Cova de Perrinho (8 objects) (Bottaini et al., 2012), Casais da Pedreira (2 objects) (Bottaini et al., 2012), Coles de Samue (18 objects), Travasso (4 objects) (Leitão and Lopes, 1985), Moita da Ladra (10 objects) (Valério et al., in press). LBA/EIA Southern Portugal: Castro dos Ratinhos (5 objects) (Valério et al.,2010), Monte do Guedelha (2 objects), Vale de Tijolos ( 3 objects), Outeiro do Circo (4 objects), Salsa 3 (1 object), Cerro da Mangancha (1 object), Cabeço Redondo (4 objects), Nora Velha (1 object) (Valério et al., 2015). LBA/EIA Northern Portugal: Castro da Senhora da Aparecida (4 objects), Carpinteira (3 objects) (Bottaini, 2013), Monte da Virgem (4 objects) (Lobato, 1992/1993). EIA Southern Portugal: Palhais (7 objects) (Valério et al., 2013), Quinta de Almaraz (23 objects) (Valério et al., 2012).

elongated terminal knob (Rocanes type) (inv. nr. 81.06 to 81.11), six bracelet-shaped objects (inv. nr. 81.12 to 81.17), and one chisel (inv. nr. 81.18) (Fig. 2) (Ferreira and Lapa, 1991; Pereira, 1971).

Available information about the circumstances of this find are quite incomplete e poorly documented. In fact, the metals were accidentally found during agricultural activities and then purchased from an antique dealer in the 1960s. Thus, the precise location and landscape where the objects were buried is unknown although it is plausible that the deposition of the metals took place in a non-settlement location.

In functional terms, the metals from Coles de Samuel comprise tools (axes, sickles and a chisel) and artefacts of unknown functionality (bracelet-shaped objects) belonging to five different typologies (palstave, socketed axes, sickles, chisel and bracelet-shaped objects) which denote a strong regional connotation, being usually considered as typical productions from Northern and Central Portugal, possibly produced during the first quarter of the I millennium BC (Coffyn, 1985).

With respect to typology, Coles de Samuel hoard reproduces a common pattern as regards the combination between specific kinds of objects: for instances, socketed axes and palstaves have been found in association in the hoards from Cabeço de Maria de Candal (Bottaini, 2013; Gutiérrez Neira et al., 2011; Vilaça et al., 2012b) and Casais da Pedreira (Bottaini, 2013; Bottaini et al., 2012); palstaves and sickles are known in the hoards of Travasso (Leitão and Lopes, 1985), Porto do Concelho (Jalhay, 1944; Bottaini, 2013; Bottaini et al., 2015) and Moura da Serra (Coffyn, 1985); a socketed axe was associated with bracelet-shaped objects in the Casal dos Fiéis de Deus hoard (Vasconcelos, 1919-20; Melo, 2000), etc.

The combination between certain tools (palstaves, socketed axes, sickles and chisels) is a recurrent element among the multiple hoards from LBA of Central Portugal while, on the contrary, the presence of other types of artefacts such as weapons (i.e. swords and spear-heads) is generally an exception. According to this situation, and although we lack information on most of these finds, some researchers have pointed out that we may be dealing here with hoards that could metaphorically represent a selection of objects linked to work and everyday activities (Bottaini, 2013; Vilaça, 2006; Vilaça et al., 2012b).

From a physical point of view, all the metals from Coles de Samuel show clear traces of wear and use, just like nicks, cracks and scratches mainly concentrated along the cutting edges. Socketed axes 81.02, 81.03 and 81.04 also present an asymmetric cutting edge, possibly resulting of blades re-sharpening and/or reforging processes (cf. Moyler, 2008). Four of the sickles are complete, while two are lacking their tips. The single-looped palstave has the blade missing and five of the bracelet-shaped objects (from 81.13 to 81.17) are not whole as well. It is quite hard to determine whether these objects have been intentionally broken before their deposition or if their destruction has been the consequence of ritual acts, as some researchers admit in this kind of situation (Nebelski, 2000; Perea, 2008).

Regardless of interpretative issues, the presence of broken and incomplete artefacts is a common characteristic in a number of multiple hoards from Central Portugal: besides Coles de Samuel, this is the case of Quinta do Ervedal (Coffyn, 1985), Casal de Fiéis de Deus (Vasconcelos, 1919-20; Melo, 2000), Porto do Concelho (Jalhay, 1944), Moura da Serra (Coffyn, 1985), etc.

By combining all the available archaeological information, we can observe that in most of these deposits, although an object is broken into two or more parts, only one of these fragments has been hoarded, being the rest of such artefact lacking and probably intended for other purposes (i.e. recycling and remelting of the metal or reuse of the fragments) (Fontijn, 2002; Nebelski, 2000).

To sum up, the empirical evidences from Central Portugal show that Coles de Samuel could be part of a practice of hoarding common to LBA and characterised by the repetitiveness of certain typological combinations and by the co-existence of worn, entire and fragmented artefacts inside the same deposit. The Coles de Samuel hoard could therefore materialize widespread beliefs that seem to suggest that depositional practices implied a deliberate selection of such artefact or part of it, also allowing identifying the existence of a social behaviour with ideological and accepted cultural meanings shared between the ancient communities living in Central Portugal during the last phase of Bronze Age.

\section{Experimental}

EDXRF measurements were performed using a Pd anode X-ray generator. In front of the detector, a He gas flow was established (about 0.2$0.3 \mathrm{l} / \mathrm{min}$ ) for light elements detection and for the detection of L-and M-

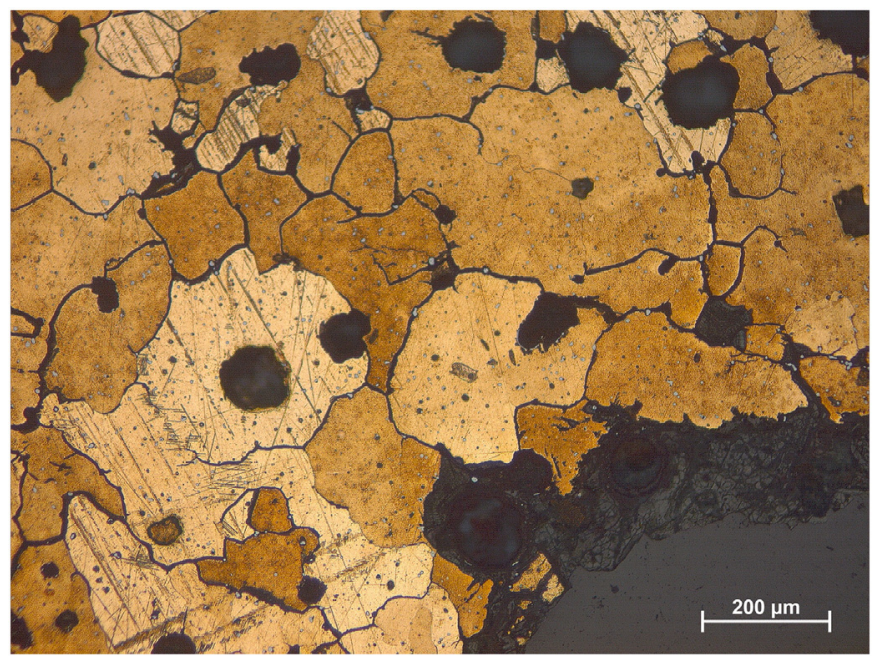

Fig. 4. OM micrographs from the cross-section of the palstave (inv. nr. 81.01) showing a dendritic microstructure characteristic of an as-cast alloy. 





lines of $\mathrm{Sn}, \mathrm{Sb}$ and $\mathrm{Pb}$. The angle between the incident and emitted beam was $50^{\circ}$. Energy resolution was $160 \mathrm{eV}$ at $5.9 \mathrm{keV}$. Samples surfaces were placed at $53 \mathrm{~mm}$ distance from the tube and $22 \mathrm{~mm}$ from the detector. XRF spectra were processed by means of the WinAxil software package. A fundamental parameter method was used to extract the concentrations of the various elements, using certified reference material BCR-691. The X-ray generator was operated at $40 \mathrm{kV}$ and $20 \mu \mathrm{A}$, with an acquisition time of $120 \mathrm{~s}$.
X-ray fluorescence results from Coles de Samuel were then correlated with the data from other collection of metals from the LBA and EIA from Portuguese territory through a principal component analysis (PCA) approach. PCA was performed with OriginLab v8 software on specific chemical elements ( $\mathrm{Sn}, \mathrm{Pb}$ and $\mathrm{Fe}$ ) with the aim to understand how different alloys were distributed in space and time. This statistical method proved to be a useful tool to discriminate group and meaningless variations within the set of metals considered, thus highlighting
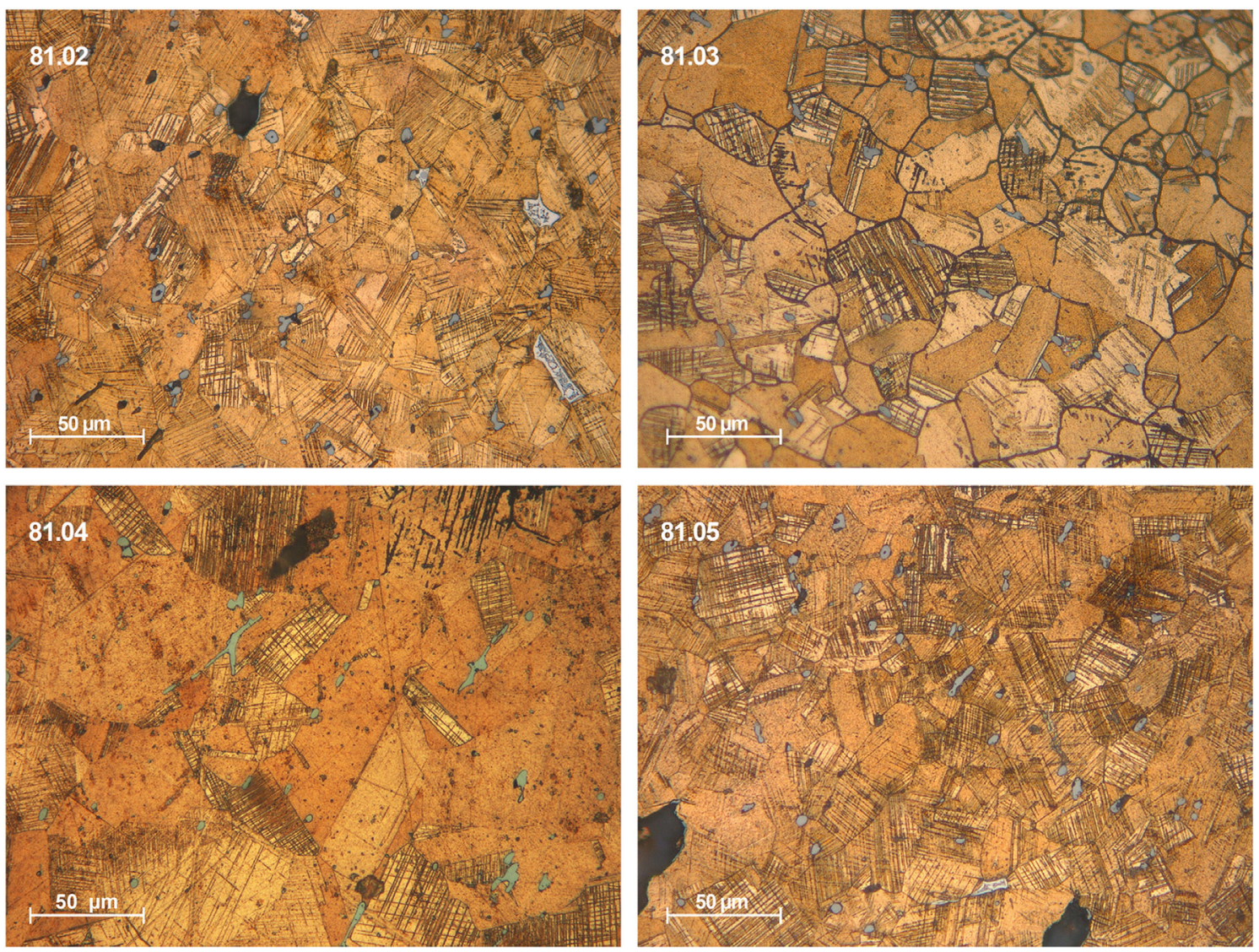

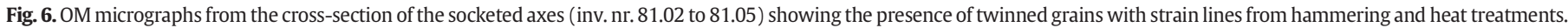



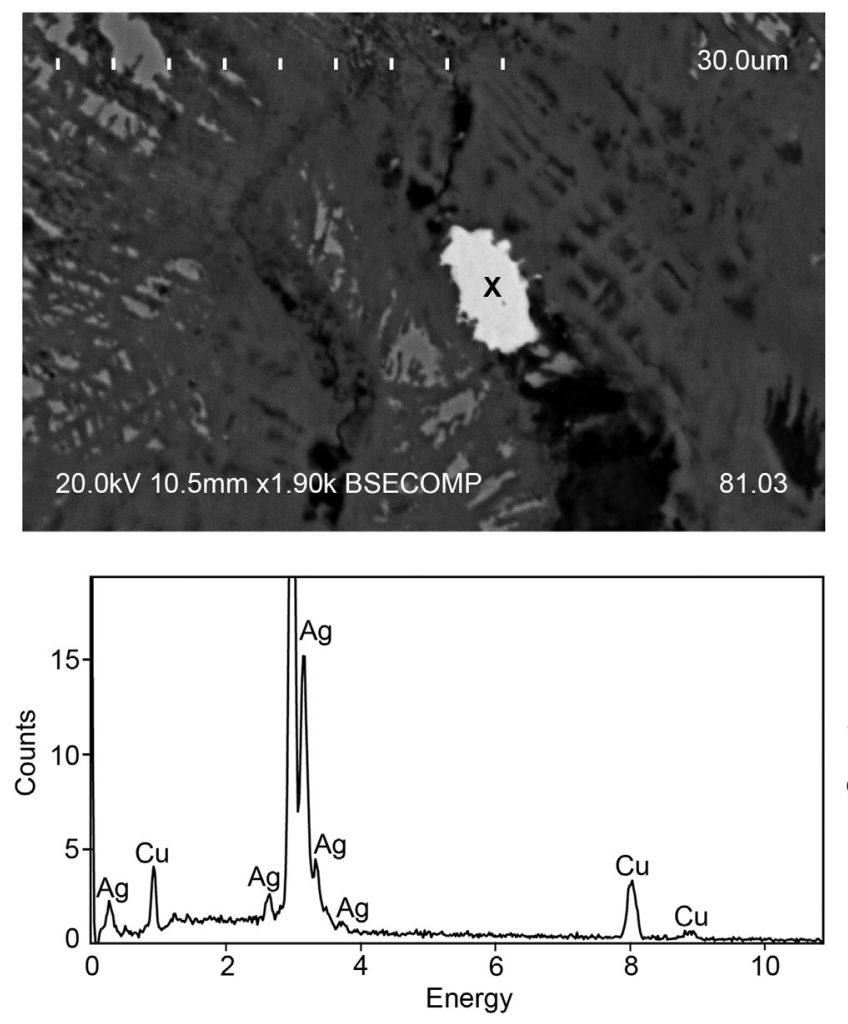

Fig. 7. Backscattered electron image with EDS spectra of an Ag-rich inclusion from the socketed axe 81.03 .

compositional differences both in a geographical and diachronic perspective.

The microstructure of the bronzes was investigated on crosssections by optical microscopy: samples were mounted on resin, grounded, polished, and etched with $\mathrm{FeCl}_{3}$ and $\mathrm{HCl}$ in a solution of ethanol, according to a standard metallographic protocol (Scott, 1991). Metallographic observations were performed with an optical microscope Leica DM2500P, equipped with a digital camera Leica MC170HD, coupled to a computer with the LAS V 4.4.0 software, with the aim to provide information about thermo-mechanical treatments performed on the finished objects. This study was completed by exploring the images obtained by SEM with backscattering electrons detector and microanalysis by Energy Dispersive X-ray Spectrometry (SEMEDS). For this purpose, a Hitachi S-3700N interfaced with a Quantax EDS microanalysis system equipped with a Bruker AXS Xflash Silicon Drift Detector (129 eV Spectral Resolution at FWHM/Mn K $\alpha$ ) was used. Quantitative elemental analysis was processed with the Bruker ESPRIT software with the followings operating conditions: backscattered electron mode (BSEM), accelerating voltage of $20 \mathrm{kV}$, working distance of $\sim 10 \mathrm{~mm}$ and emission current of $90 \mu \mathrm{A}$.

\section{Results and discussion}

\subsection{EDXRF}

The chemical results show that all the artefacts from Coles de Samuel are binary $\mathrm{Cu}-\mathrm{Sn}$ bronze alloys with $\mathrm{Pb}$, As and $\mathrm{Fe}$ as minor constituents (Table 1).

This data partially agrees with a previous analytical study carried out on nine objects from this collection (five axes, two sickles, one braceletshaped object and the chisel) and performed by optical emission spectroscopy in the second half of the 1970s (Coffyn, 1985).

The amount of tin ranges from $8.7 \pm 0.9$ to $13.0 \pm 1.0 \mathrm{wt} \%$, indicating that the artefacts were produced with good-quality melted binary tin bronzes. The control over the final tin content is very important to obtain a metal with adequate physical properties, since the amount of Sn affects the thermo-mechanical behaviour of the alloy during the forging and annealing processes. In accordance with the Cu-Sn diagram, the addition of $\mathrm{Sn}$ to $\mathrm{Cu}$ reduces the melting temperature resulting in a better castability of the alloy. A bronze with $~ 10 \mathrm{wt} \%$ Sn can be considered to have good castability properties and thermomechanical treatments can make the metal tough enough to absorb and disperse some of the energy resulting from any impact arising from the use of the objects.
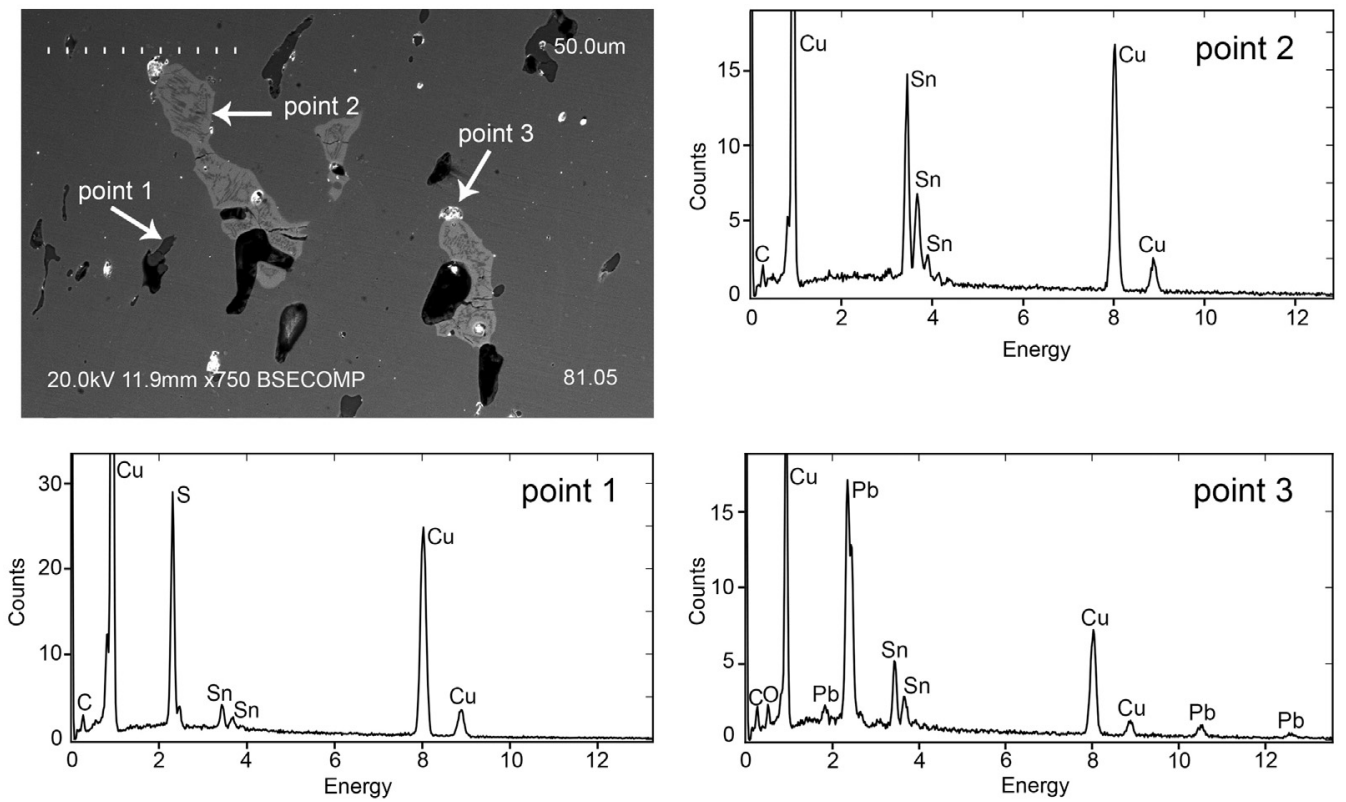

Fig. 8. Backscattered electron image with EDS spectra of a Cu-S inclusion (point 1), $\alpha+\delta$ phase (point 2), and Pb inclusions (point 3 ) from the socketed axe 81.05. 

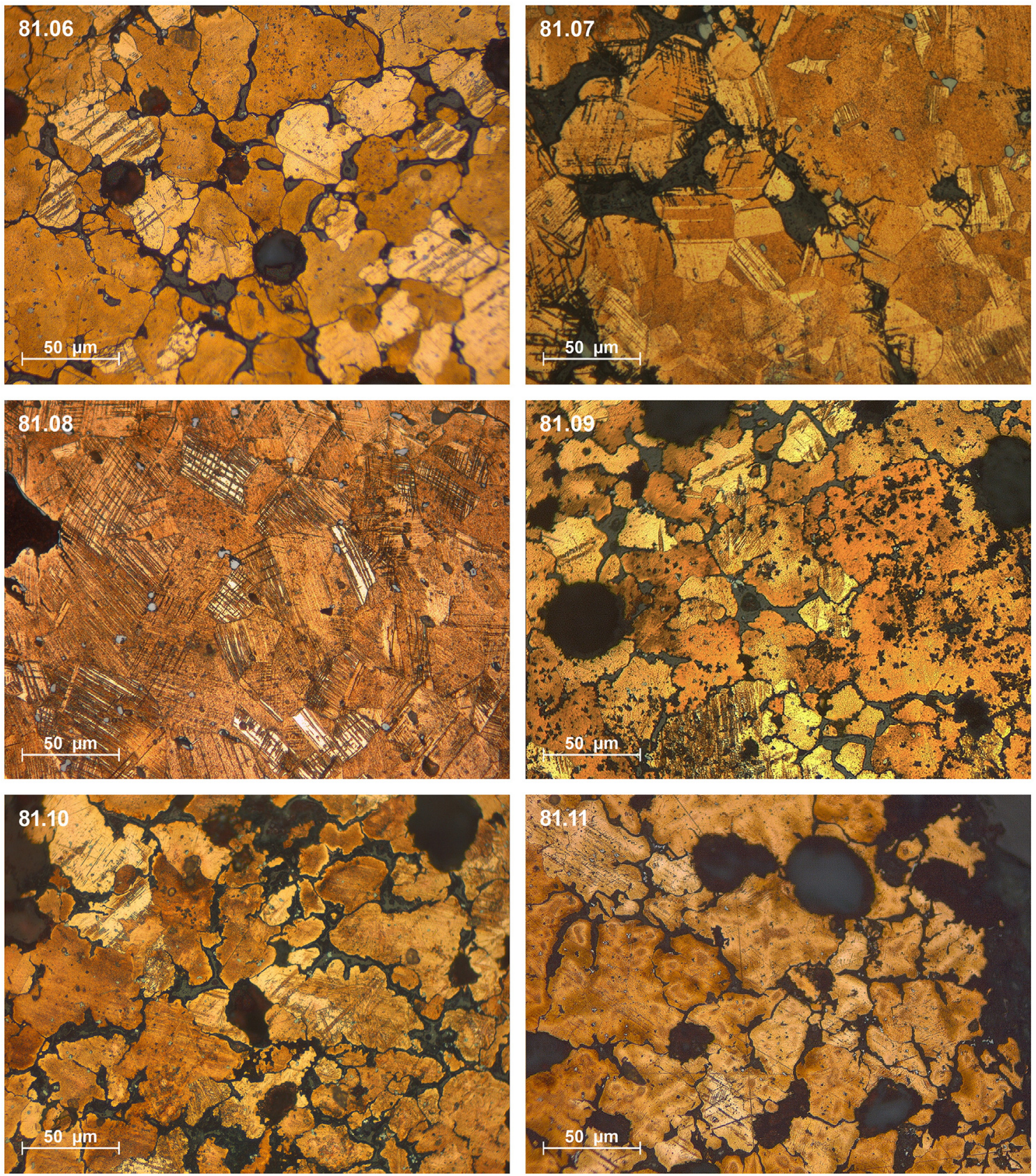

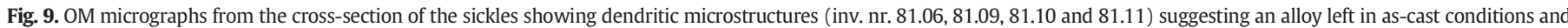
twinned grains with slip bands from forging and annealing work (inv. nr. 81.07 and 81.08).

By contrast, an excessive tin content ( 15 wt\% according with modern phase diagrams) may increase the metal's brittleness due to the formation of the $\alpha+\delta$ eutectoid phase that make the objects more difficult to forge.

The Sn content detected in the metals from Coles de Samuel results to be quite constant regardless the type or the function of the artefacts. In fact, significant differences in tin amount are not evident between objects that due to their functionality would require a high mechanical strength such as axes, sickles and chisel, and those artefacts with a likely ornamental function, such as bracelet-shaped objects.

Comparing the metals from Coles de Samuel with others LBA/EIA hoards and sites from Central Portugal, a quite standardised framework can be drawn with respect to Sn amount, since in most cases Cu-based metals can be grouped in a range between $10 \mathrm{wt} \%$ and $15 \mathrm{wt} \% \mathrm{Sn}$. Some examples can be found both in hoards and sites, such as
Freixianda (average of $\sim 14$ wt\% Sn) (Gutiérrez Neira et al., 2011), Vila Cova de Perrinho (average of $\sim 10 \mathrm{wt} \% \mathrm{Sn}$ ), Casais da Pedreira (average of $\sim 10.3 \mathrm{wt} \% \mathrm{Sn}$ ), Moinho do Raposo $(10.17 \pm 0.04 \mathrm{wt} \% \mathrm{Sn}$ ) (Bottaini et al., 2012), Medronhal (average of $\sim 13.1 \mathrm{wt} \% \mathrm{Sn}$ ) (Figueiredo et al., 2013) and Moita da Ladra (average of 11.6 wt\% Sn) (Valério et al., in press).

A twofold interpretation can be given to the steady percentage of tin in the LBA/EIA from Central Portugal: on one side, it shows that ancient metalworkers were able to have some control over the tin content in the alloy suggesting that good mechanical properties mattered and were appreciated; on the other side, the regular tin content of bronzes from Coles de Samuel also indicates that communities that produced these metals had a constant access to tin sources.

Among minor elements, iron, arsenic and lead have also been detected and occur up to about $1.1 \mathrm{wt} \%$ in total. The presence of these 


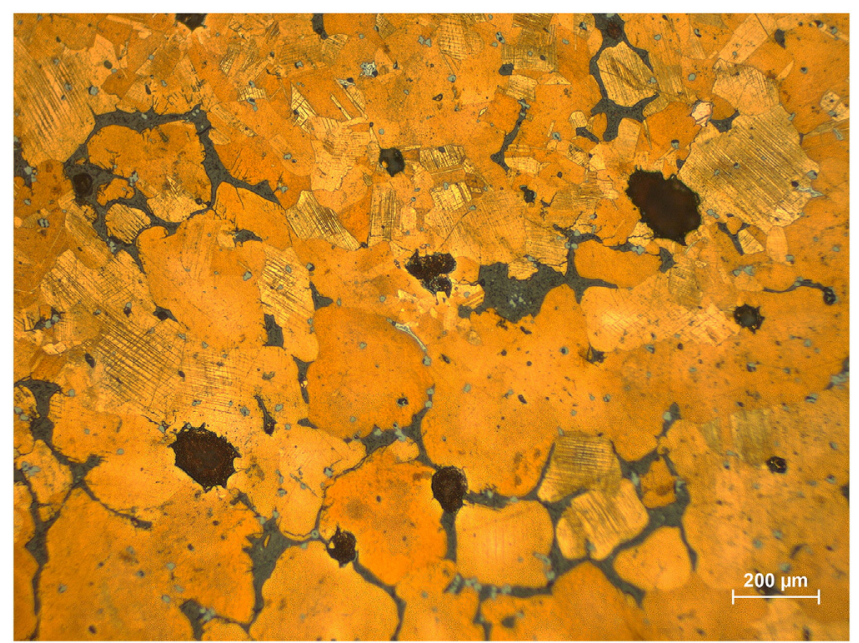

Fig. 10. OM micrograph from the cross-section of the sickles 81.07 showing a transition area between the dendritic structure (lower part of the image) and annealing twins and slip lines in some grains (upper part of the image) evidencing a selective application of thermomechanical treatments.

impurities is quite recurrent in the LBA/EIA metallurgy from Western Iberian and is usually connected with the occurrence of these metal compounds in the copper ores used.

The low Fe pattern is generally interpreted as a technological indicator of a quite simple smelting process that would produce a metal with very low iron content, not exceeding 0.05 wt\% Fe (Craddock and Meeks, 1987). During prehistoric times in the Portuguese territory, as well as in the rest of the Iberian Peninsula, the smelting technology showed a very conservative character. In fact, since the dissemination of metallurgy, in the transition between the 4th and the 3rd millennium BC (Soares and Cabral, 1993), smelting operations were carried out in open smelting crucibles placed in direct contact with the fire. New metallurgical practices were not introduced until the LBA/EIA with the rise of a more efficient copper smelting technology, consisting in the use of closed furnaces able to achieve higher temperatures and stronger reducing conditions (Rovira Llorens, 2004; Rovira Llorens and Ambert, 2002; Rovira Llorens and Montero-Ruiz, 2013). Consequently, as result of the introduction of this new smelting method, Fe content increases in $\mathrm{Cu}-$ based metals, mainly in Southern Portugal (Schiavon et al., 2013; Valério et al., 2015).

Within this scenario, it is worth to be highlighted that the iron content of the artefacts from Coles de Samuel is very low, suggesting that the metals buried in this hoard were produced by local communities before the dissemination of this new smelting technology. This is in agreement with the indigenous LBA/EIA metallurgy from Central Portugal that is characterised by an iron content below $0.05 \mathrm{wt} \%$, as documented in a number of hoards and habitats (Bottaini, 2013), such as Freixianda (Gutiérrez Neira et al., 2011), Vila Cova de Perrinho (Bottaini et al., 2012), Castro de Argemela (Vilaça et al., 2012a) and Baiões (Figueiredo et al., 2010; Valério et al., 2006).
Lead also occurs as impurity. From a structural point of view, its addition improves the fluidity of the molten metal but reduces the alloy's hardness due to the low miscibility of $\mathrm{Pb}$ in copper, leading to the formation of small $\mathrm{Pb}$ rich globular segregates which crystallize along the grain boundaries making the metal more brittle and difficult to work. Lead contents lower than $2 \mathrm{wt} \%$ generally indicate that this element was not intentionally added in the alloy but it could depend on its presence as minor element in the primary ores used in the smelting process (Tylecote, 1992).

The residual occurrence of $\mathrm{Pb}$ in the objects under study was an expected result, since low $\mathrm{Pb}$ content is a recurrent feature within the LBA/ EIA metallurgy from Central and Southern Portugal, as from most of the Iberian Peninsula. In fact, notwithstanding the caution that should be applied when comparing quantitative chemical results obtained with different analytical techniques and methodologies, the sporadic presence of $\mathrm{Pb}$ detected in the Coles de Samuel collection is characteristic of a number of hoards and habitats from the region (Bottaini, 2013; Bottaini et al., 2012; Figueiredo et al., 2010; Figueiredo et al., 2013; Gutiérrez Neira et al., 2011; Valério et al., 2006; Valério et al., 2007; Valério et al., 2010; Vilaça, 1997).

High-leaded tin bronze, in contrast, are more common in the LBA/ EIA and are mainly linked to the production of palstaves in Galicia and Northern Portugal, gravitating within the so called Atlantic Bronze Age (Bottaini, 2013; Montero-Ruiz et al., 2003).

Fig. 3 shows a statistical multivariate analysis (PCA) applied on the matrix dataset composed of the XRF data from Coles de Samuel and from other collection of metals from Late Bronze Age and Early Iron Age from the Portuguese territory. The PCA confirms that the chemical composition of metals from Coles de Samuel (8-13 wt\% Sn, <2 wt\% Pb and low contents of minor elements) is in agreement with a LBA/EIA metallurgy from Central Portugal, suggesting a local production of these artefacts. In fact, in a regional perspective, Cu-based metals from Central Portugal show a slightly higher tin content and reduced impurities of iron with respect to those produced under the Phoenician influence, in the Southern Portuguese territory since the EIA. At the same time, lead appears as impurities, unlike the productions widespread in the Northwestern Iberian Peninsula during the LBA/EIA.

\subsection{Metallurgical analysis}

Optical Metallography (OM) and Scanning Electron Microscopy with $\mathrm{X}$-ray microanalysis (SEM-EDS) has been used to characterise the artefacts from a microstructural point of view. These techniques allowed to identify metallic phases, inclusions and to observe the typology and morphology of the grains, recrystallization twins and/or deformation bands, thus reconstructing backwards the processes that ancient metalworker applied in the manufacture of the artefacts. The data is presented and discussed based on a typological approach.

\subsubsection{Palstave}

The microscopic observation of palstave 81.01 was made in the proximal area of the axe, not corresponding to the cutting edge that is lost. The metallographic image shows the presence of grains whose
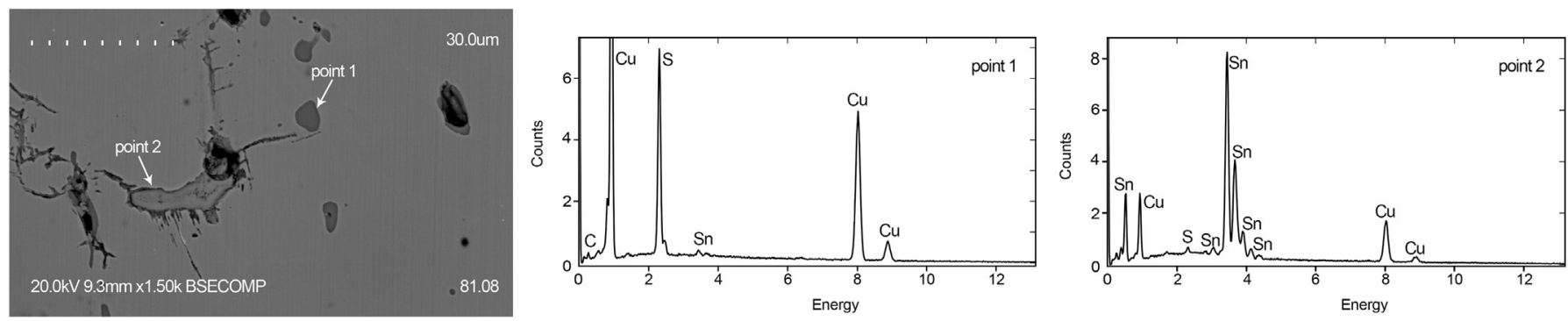

Fig. 11. Backscattered electron image with EDS spectra of the socketed axe 81.08 showing the occurrence of a Cu-S inclusion (point 1 ) and $\alpha+\delta$ phase (point 2 ). 



Fig. 12. Backscattered electron image with EDS spectra of the socketed axes showing an Au inclusion (81.06), Ag inclusion (inv. nr. 81.07) and Pb inclusion (inv. nr. 81.07).

morphology suggests that the palstave medial region has not been submitted to any thermo-mechanical treatment. The shape of the holes left by gas inclusions during casting as well as the globular morphology of the Cu-S also confirms this interpretation (Fig. 4).

This result points out a different operational sequence with respect to other one single-looped palstaves from Central Portugal: in fact, the palstaves from Freixanda (Gutiérrez Neira et al., 2011; Vilaça et al., 2012b), Casais das Pedreiras (Bottaini et al., 2012), and Porto do Concelho (Bottaini, 2013) show a microstructure suggesting that objects were finished with one or more cycles of forging and annealing. This kind of treatment would make the cutting edge harder and thermo-mechanically more appropriate to withstand stronger impacts. Nevertheless, the discrepancy between the palstave from Coles de Samuel on one side and the rest of the metallographed ones on the other, may be explained with the fact that observation has been made in different areas of the object.

SEM-EDS analysis confirms the presence of $\mathrm{Cu}-\mathrm{S}$ inclusions and also reveals the occurrence of very small globular unalloyed inclusions rich in $\mathrm{Pb}$ and $\mathrm{Ag}$. This kind of inclusions have already been reported in LBA bronzes from the Portuguese territory and can be likely considered as micro-inclusions from the original ore material used in the production of the artefacts (Figueiredo et al., 2011). Moreover, and although a relatively low tin amount ( $10 \pm 1 \mathrm{wt} \%$ ), the $\alpha+\delta$ eutectoid phase has been observed as well (Fig. 5). This situation suggests that heat treatment that ancient metalworkers applied during the production of the palstave has not been high enough to completely homogenize the microstructure of the alloy.

\subsubsection{Socketed axes}

The four socketed axes (inv. nr. 81.02 to 81.05) have been sampled in the cutting area. The microstructure of the etched samples shows the presence of equiaxed grains with annealing twins and strain lines, suggesting the application of one or more cycles of forging plus annealing. The presence of the strain lines can indicate the use of a final plastic deformation.

Despite the application of the longest operational sequence for the manufacturing of the axes 81.02 and 81.05 , the $\alpha+\delta$ eutectoid is still visible, suggesting that annealing and forging cycles were not sufficient to completely homogenize the alloy. The occurrence of elongated $\mathrm{Cu}-\mathrm{S}$ inclusions is a common feature observed in the microstructures of this
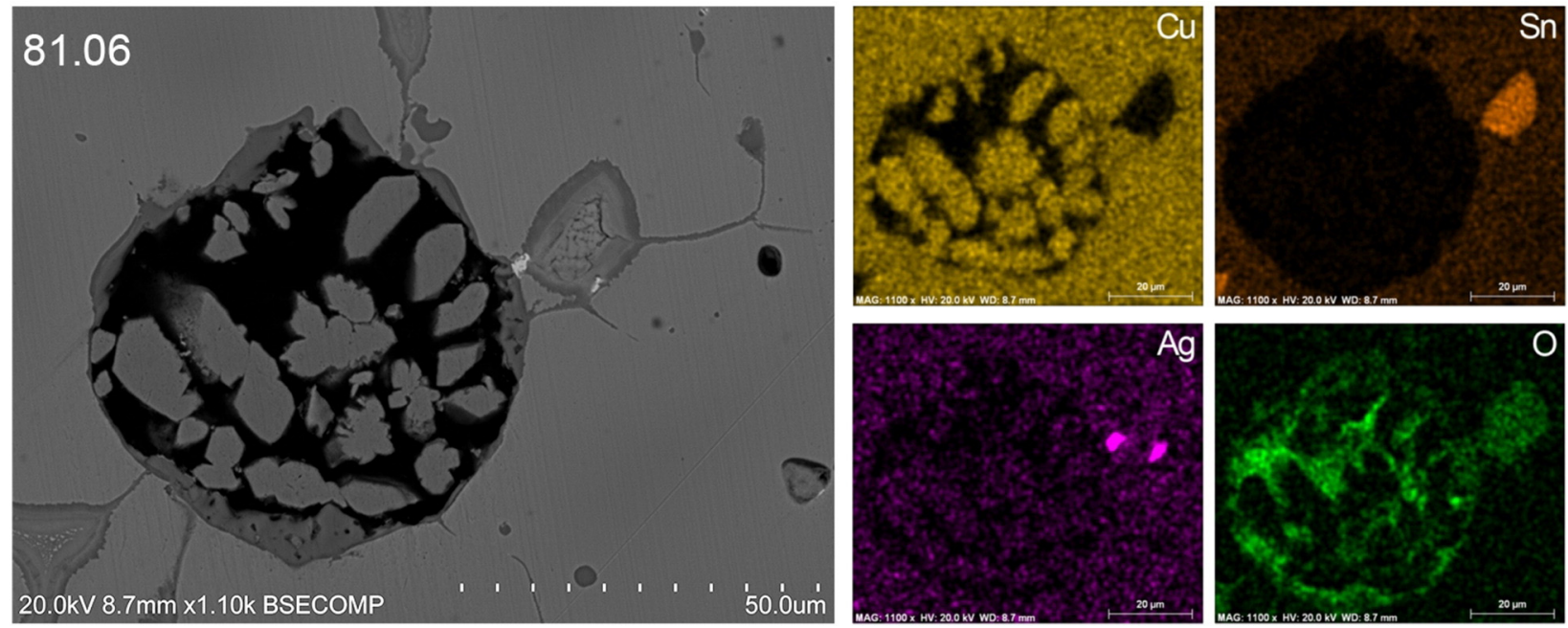

Fig. 13. Backscattered electron image with EDS elemental distribution maps of a globular unalloyed Cu-inclusion observed in the sickle 81.06. 



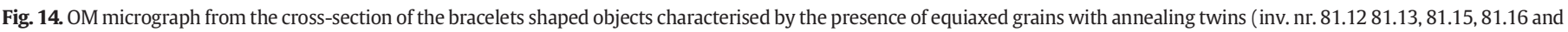
81.17) with strain bands (inv. nr. 81.14), suggesting the combination between mechanical and thermal operations.

group of socketed axes also confirming the deformation degree applied in order to obtain the final objects morphology (Fig. 6).

Metallographic analyses of socketed axes in the region are quite scarce and performing a comparative study is therefore not an easy task. However, four specimens from the hoard of Freixianda (Gutiérrez Neira et al., 2011; Vilaça et al., 2012b) and one from Moinho do Raposo (Bottaini, 2013) have been recently studied. With the exception of one fractured and incomplete socketed axe from Freixianda, which presents a dendritic as-cast microstructure, the remaining ones are characterised by the occurrence of deformed equiaxial grains with annealing twins and slip bands evidencing the application of thermomechanical treatments.

Also in the case of socketed axes, the SEM-EDS characterisation allowed the identification of some of the most common inclusions observed in the LBA metals from the Portuguese territory (Figueiredo et al., 2011), namely Ag (Fig. 7), Pb and Cu-S, as well as the $\alpha+\delta$ eutectoid richer in tin (Fig. 8). This might be the result of the exploitation of mineral resources with the presence of these micro-inclusions compounds.

\subsubsection{Sickles}

Fig. 9 shows the microstructure of the sickles (inv. nr. 81.06 to 81.11 ). The artefacts $81.06,81.09,81.10$ and 81.11 exhibited an as-cast microstructures constituted by dendritic morphology which means that they would not have been subjected to any post-casting treatment after being removed from their respective moulds. For reasons of accuracy, it should be underlined that these results were obtained in nonfunctional areas of the sickles. In fact, observing their blades, the 

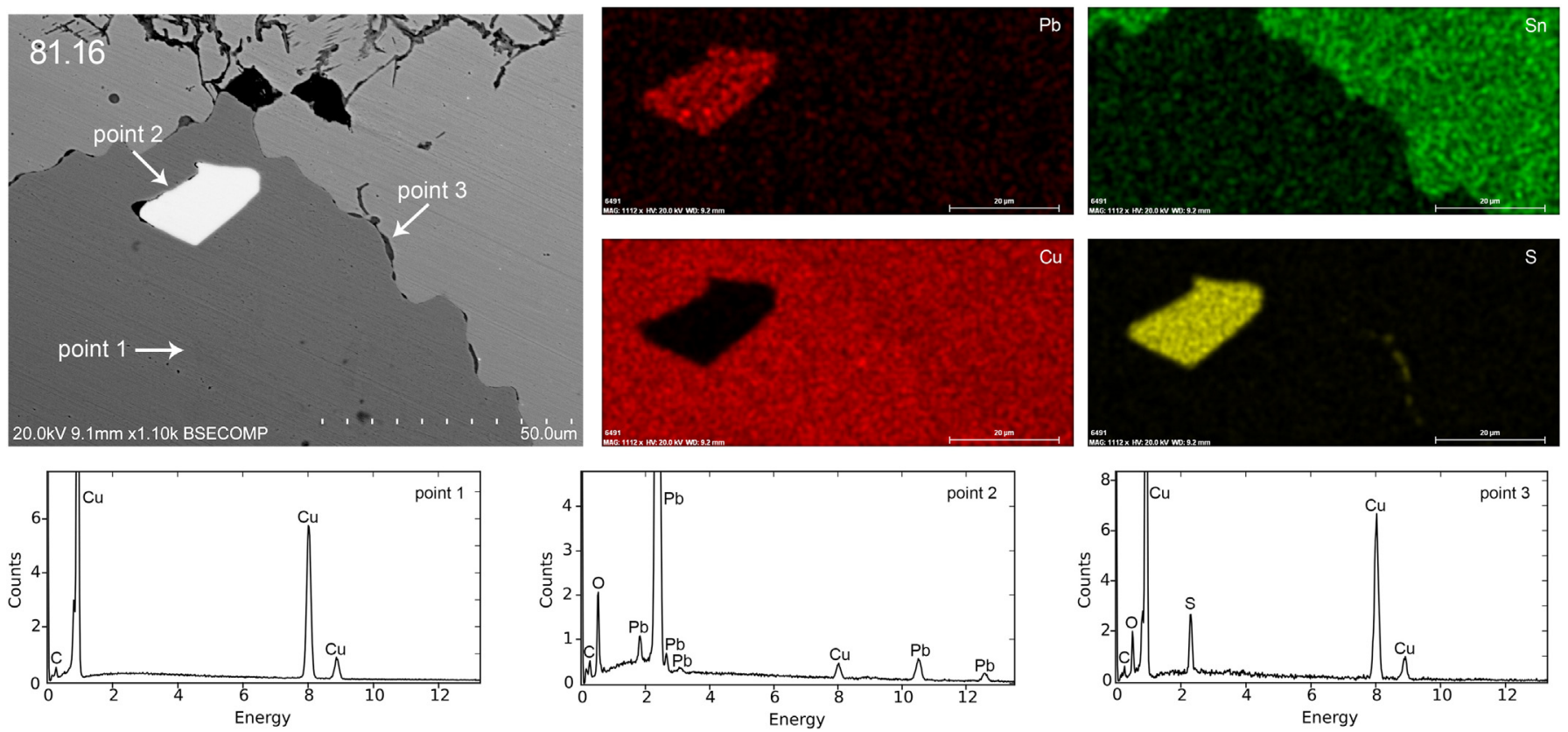


inclusion (point 1), a Pb inclusion (point 2) and a Cu-S inclusion (point 3).

presence of cracks and scratches is clear, empirically indicating that these objects could be involved in practical activities before being buried, regardless the microstructural features observed.

Unlike the previous ones, sickles 81.07 and 81.08 showed an equiaxial microstructure with twined grains and slip bands, suggesting that the manufacturing process consisted of cycles of annealing and hammering. The observation of the microstructure from the sickles 81.07, in particular, allowed identifying the transition area between the inner as-cast dendritic microstructure and the outer zone with the presence of grains resulting by annealing and forging processes (Fig. 10). These results, that point out to a selective application of post-casting treatments to the cutting edge, also show how the sampled area is determinant for the identification of the microstructure and thus

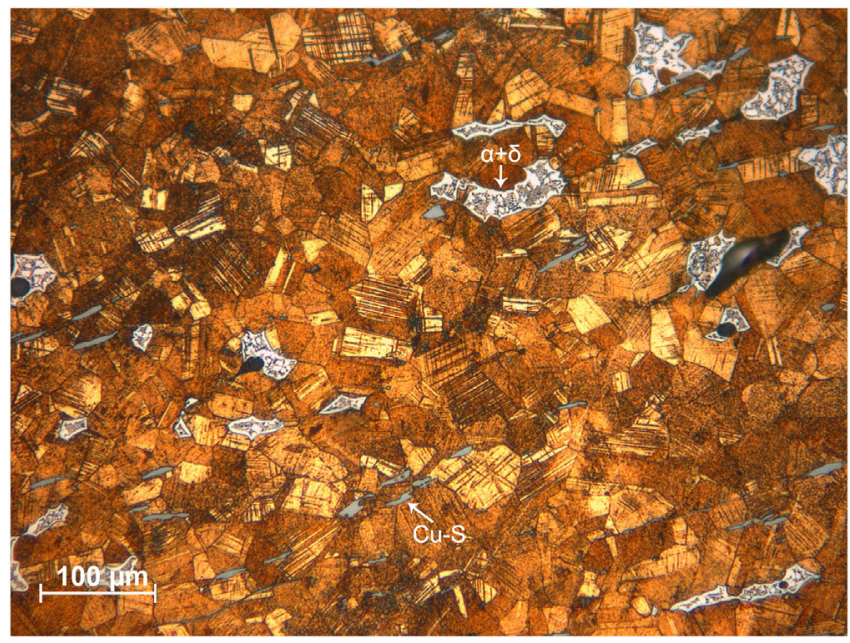

Fig. 16. OM micrograph from the cross-section of the chisel (inv. nr. 81.18) showing a microstructure characterised by the occurrence of equiaxial grains with annealing twins and slip bands which suggest that thermal and mechanical treatments were applied during the manufacture of the object. The elongated morphology of $\mathrm{Cu}-\mathrm{S}$ in the line of working also confirms the intensity of the plastic deformation. The $\alpha+\delta$ eutectoid phase is clearly visible as well. for the interpretation of the data and the understanding of the operational sequence.

A very reduced number of sickles from Western Iberia have been observed by OM and there are very few parallels. Two items from Porto do Concelho were recently analysed. Both samples were removed from functional areas of the artefacts, showing a shape-casting structure as well (Bottaini, 2013).

The SEM-EDS clearly evidences a copper-rich $\alpha$-phase matrix and the $\alpha+\delta$ eutectoid richer in tin both in the areas between the dendrite arms and in the intergranular spaces: in the latter case, the presence of the $\alpha+\delta$ phase suggests that post-casting treatments, selectively applied to the cutting edge of the sickle, were not adequate to homogenize the metal. The presence of numerous inclusions, namely Cu-S (Fig. 11), Au-rich and Ag-rich micro-inclusions and $\mathrm{Pb}$ globules were also detected (Fig. 12) being their occurrence likely dependant on the ores used for metal production. Gold, for example, may be associated with Sn deposits derived from hydrothermal fractionation of in the Hercynian Tin-bearing granites commonly present in Central and Southern Portugal (Neiva, 2002) and cassiterite $\left(\mathrm{SnO}_{2}\right)$ and gold can sometimes occur simultaneously in the same vein or alluvial placer deposit (Dube, 2006). Their presence in the alloy could be therefore interpreted as a natural association within the ores used in the manufacture of these artefacts. Since Au and Ag-rich inclusions are generally associated with corrosion areas, it is likely that they result of selective corrosion and redeposition in the metal. Finally, globular unalloyed $\mathrm{Cu}$-inclusions surrounded by $\mathrm{Cu}-\mathrm{S}$ inclusions have been detected as well (81.06 and 81.07) (Fig. 13). The occurrence of this particular microconstituent is a rather common feature of ancient bronzes (Silva et al., 2008; Wang and Merkel, 2001), and its formation is generally considered as the result of a copper redeposition process resulting from corrosion phenomenon (Bosi et al., 2002; Emami and Bigham, 2013).

\subsubsection{Bracelets shaped objects}

The six objects belonging to this metallic type (inv. nr. 81.12 to 81.17) reveal very similar microstructural features, having been casted, annealed and forged: their microstructure shows twinned grains from hammering and heat treatments. The presence of the strain lines in the microstructure of the bracelet 81.14 suggest that this artefact was 

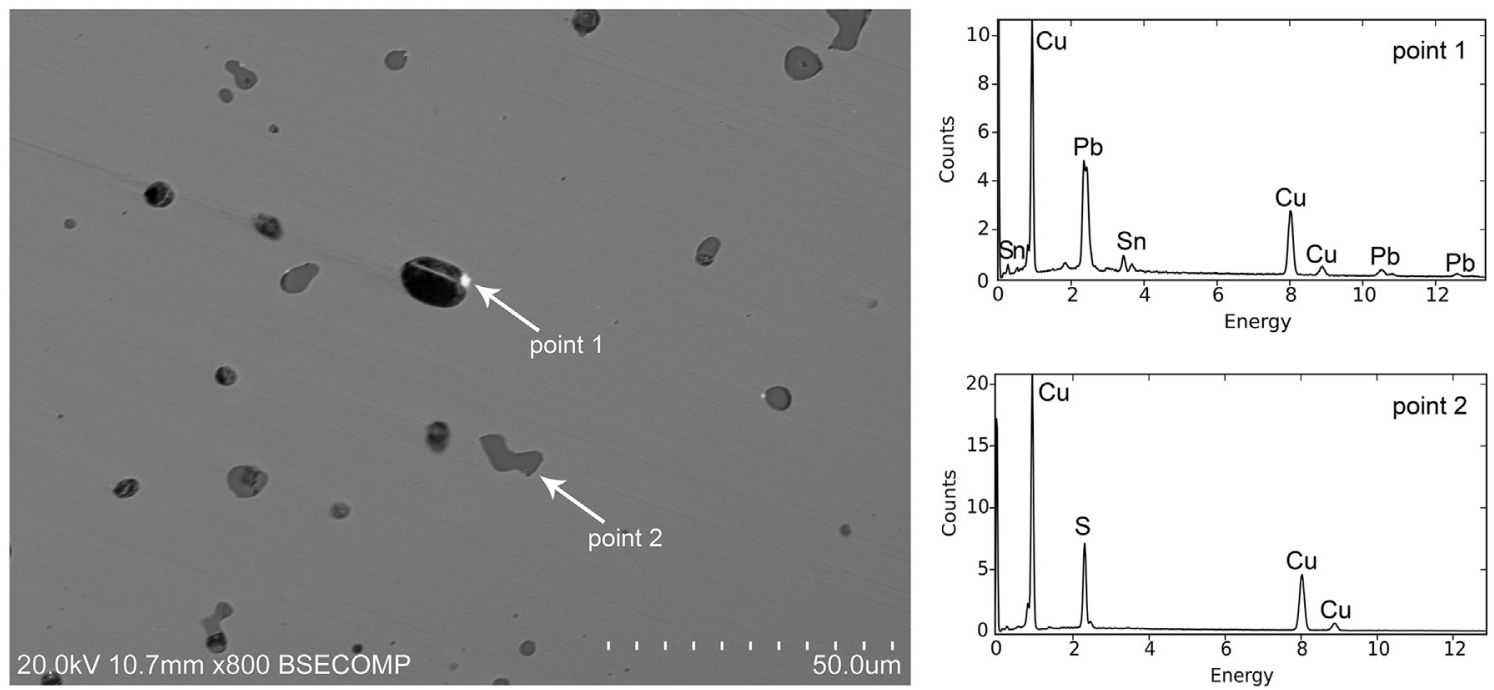

Fig. 17. Backscattered electron image with EDS spectra of the chisel showing Pb inclusions (point 1) and Cu-S inclusions (point 2 ).

submitted to a final plastic deformation. OM also revealed the presence of the $\alpha+\delta$ eutectoid microstructure (inv. nr. 81.12 and 81.13) (Fig. 14).

The cross section of some of these artefacts, partly circular and partly quadrangular (inv. nr. 81.13 to 81.16), could suggest that these objects were manufactured from small bars with circular cross section, to which the desired shape was given through forging and annealing cycles. Bracelet-shaped objects from other archaeological contexts such as Porto do Concelho and Vila Cova de Perrinho, for instance, show similar microstructure, suggesting analogous operational sequences (Bottaini, 2013).

The SEM-EDS characterisation of the object 81.16 highlights the presence of non-spherical unalloyed twinned $\mathrm{Cu}$ grains surrounded by $\mathrm{Cu}-\mathrm{S}$. The formation of this kind of structure is generally associated with corrosion mechanisms of the alloy (Bosi et al., 2002; Emami and Bigham, 2013). As has been already observed in the rest of the collection from Coles de Samuel, Pb-rich inclusions are also visible (Fig. 15).

\subsubsection{Chisel}

The microstructure of the chisel (inv. nr. 81.18) shows very small equiaxed grains with twinned grains, plus fracture lines, caused by a process of successive annealing and forging to shape the cutting edge of the object. The Cu-S inclusions have an elongated morphology along the preferential deformation plane of the artefact, confirming the application of thermo-mechanical treatments, not sufficient, however, to homogenize the biphasic microstructure characterised by the presence of the $\alpha+\delta$ eutectoid phase (Fig. 16).

Metallographed chisels from Central Portugal, namely from Freixianda and Vila Cova de Perrinho, regardless of their shape and morphology, also suggest an intense annealing and hammering treatment for this kind of artefacts (Bottaini, 2013; Vilaça et al., 2012b).

Finally, the SEM-EDS image of the sampled area displays the presence $\mathrm{Cu}-\mathrm{S}$ inclusions. Due to its low miscibility in molten alloy and in accordance with other artefacts of the collection, globular inclusions of lead have been also observed (Fig. 17).

\section{Conclusions}

This study presents a new insight on the metallurgical characteristics of metals buried inside hoards from the LBA in Western Iberia. The chemical and metallographic examinations of the metals from Coles de Samuel allowed the identification of the composition and microstructure of the studied alloys, providing information on the technological choices that ancient metalworkers made during the metallurgical process.

The EDXRF analytical results show that this collection of metals is made of binary tin bronzes with a low impurity content ( $\mathrm{Pb}, \mathrm{As}$, $\mathrm{Fe}$ ), suggesting that the ancient metalworkers had the necessary skills to carefully control the manufacturing process in order to improve the resistance of the metal to mechanical stress and physical impacts.

The EDXRF data from Coles de Samuel combined with the PCA analysis also confirmed the identification of metallurgical traditions with regional and chronological value, reinforcing at the same time the idea that metals from Coles de Samuel have been locally produced.

The metallographic observations carried out on the functional areas of the objects confirm that most of the objects from Coles de Samuel had been adequately prepared through annealing and hammering cycles to create harder edges which make the metals mechanically more appropriate to be actively used. The only exception is represented by the palstave and by four sickles even if the metallographic observations have been carried out in a non-functional area. In any case, nearly all the tools examined display signs of wear (nicks and scratches on the cutting edges, asymmetry of the blade, cracks on the surfaces of the objects) also suggesting that these objects might be actively involved in everyday activities causing some kind of mechanical stress before being buried.

On the other side, from an archaeological point of view, it has been highlighted that the collection from Coles de Samuel reproduces a common pattern as regards the typological combination of objects which is common to other LBA hoards from Central Portugal. The repetitiveness of well-defined typological associations, with palstaves, socketed axes, chisels and bracelet-shaped objects, found inside the same archaeological context, seem to point out that the metals from Coles de Samuel could belong to a widespread pattern of selective depositions in which certain object types were intentionally associated to other peculiar ones. In this way, the metals from Coles de Samuel could be the result of structured social and cultural practices in which, through deposition, artefacts imbued with special meanings were selected and permanently removed from the everyday activities being deliberately buried in specific types of places.

\section{Acknowledgments}

This work has been financed by national funds by FCT - Foundation for Science and Technology under the UID project UID/HIS/00057/2013 (POCI-01-0145-FEDER-007702), COMPETE, FEDER, Portugal2020 and 
by the project "IMAGOS" - Innovative Methodologies in Archaeology, Archaeometry and Geophysics - Optimizing Strategies X LARES Laboratorial Archaeometric and Archaeological Research - Engaging Sciences, operation no. ALENT-07-0224-FEDER-001761 funded by the European Regional Development Fund (FEDER) through the INALENTEJO - Specific Regulation Support System Entities System National Science and Technology. Carlo Bottaini thanks Marianna Sautariello and Lorenzo Bottaini for the support during the preparation of this paper. Rui Bordalo also acknowledges FCT for the grant SFRH/ $\mathrm{BPD} / 85259 / 2012$.

\section{References}

Bosi, C., Garagnani, G.L., Imbeni, V., Martini, C., Mazzeo, R., Poli, G., 2002. Unalloyed copper inclusions in ancient bronze artifacts. J. Mater. Sci. 37, 4285-4298. http://dx.doi.org/ 10.1023/A:1020640216415

Bottaini, C., 2013. Depósitos metálicos no Bronze Final (XIII-VII A.C.) do Centro e Norte de Portugal. Aspectos sociais e arqueometalúrgicos PhD Thesis, Unpublished University of Coimbra, Coimbra.

Bottaini, C., Mirão, J., Candeias, A., Vilaça, R., Montero-Ruiz, I., 2015. A multi-analytical approach for the study of Late Bronze Age metals from Central Portugal. Microsc. Microanal. 21 (S6), 134-135. http://dx.doi.org/10.1017/S1431927614014378.

Bottaini, C., Silva, A.L.M., Covita, D.S., Moutinho, L.M., Veloso, J.F.C.A., 2012. Energy dispersive X-ray fluorescence analysis of archeological metal artifacts from the Final Bronze Age. X-Ray Spectrom. 41, 144-149. http://dx.doi.org/10.1002/xrs.2368.

Bradley, R., 1990. The Passage of Arms: an Archaeological Analysis of Prehistoric Hoards and Votive Deposits. Cambridge University Press, Cambridge, New York.

Coffyn, A., 1985. Le Bronze final atlantique dans la Péninsule Ibérique, ed. Diffusion de Boccard, Paris.

Craddock, P.T., Meeks, N.D., 1987. Iron in ancient copper. Archaeometry 29, 187-204. http://dx.doi.org/10.1111/j.1475-4754.1987.tb00411.x.

Delibes De Castro, G., 2007. ¿Para los hombres o para los dioses? Certezas y sospechas sobre la intención de los depósitos del Bronce Final Atlántico. In: Celis Sánchez, J. (Ed.), El Hallazgo Leonés de Valdevimbre Y Los Depósitos Del Bronce Final Atlántico En La Península Ibérica. Diputación de León, pp. 10-35.

Dobres, M.A., Hoffman, C.R., 1994. Social agency and the dynamics of prehistoric technology. J. Archaeol. Method Theory 1, 211-258. http://dx.doi.org/10.1007/BF02231876.

Dube, R.K., 2006. Interrelation between gold and tin: a historical perspective. Gold Bull. 39 (3), 103-113. http://dx.doi.org/10.1007/BF03215537.

Emami, M.A., Bigham, M., 2013. Mechanism of corrosion due to unalloyed copper inclusion in ancient bronzes. Surf. Eng. 29 (2), 128-133.

Ferreira, A.M., Lapa, F., 1991. Carta Arqueológica do Concelho de Soure. Câmara Municipal de Soure, Soure.

Figueiredo, E., Valério, P., Araújo, M.F., Silva, R.J.C., Soares, A.M.M., 2011. Inclusions and metal composition of ancient copper-based artefacts: a diachronic view by microEDXRF and SEM-EDS. X-Ray Spectrom. 40, 325-332. http://dx.doi.org/10.1002/xrs. 1343.

Figueiredo, E., Araújo, M.F., Silva, R.J.C., Vilaça, R., 2013. Characterisation of a Proto-historic bronze collection by micro-EDXRF. Nucl. Instr. Methods Phys. Res. Sect. B Beam Interact. Mater. Atoms 296, 26-31. http://dx.doi.org/10.1016/j.nimb.2012.11.019.

Figueiredo, E., Silva, R.J.C., Senna-Martinez, J.C., Araújo, M.F., Braz Fernandes, F.M., Inês Vaz, J.L., 2010. Smelting and recycling evidences from the Late Bronze Age habitat site of Baiões (Viseu, Portugal). J. Archaeol. Sci. 37, 1623-1634. http://dx.doi.org/10. 1016/j.jas.2010.01.023.

Fontijn, D.R., 2002. Sacrificial Landscapes. Cultural Biographies of Persons, Objects and "Natural" Places in the Bronze Age of the Southern Netherlands, c. 2300-600 BC. Analecta Praehistorica Leidensia. Faculty of Archaeology, University of Leiden.

Gosden, C., Marshall, Y., 1999. The cultural biography of objects. World Archaeol. 31 (2), 169-178. http://dx.doi.org/10.1080/00438243.1999.9980439.

Gutiérrez Neira, P.C., Zucchiatti, A., Montero-Ruiz, I., Vilaça, R., Bottaini, C., Gener, M., Climent-Font, A., 2011. Late Bronze Age hoard studied by PIXE. Nucl. Instr. Methods Phys. Res. Sect. B Beam Interact. Mater. Atoms 269, 3082-3086. http://dx.doi.org/ 10.1016/j.nimb.2011.04.072.

Hamon, C., Quilliec, B., 2008. Hoards From the Neolithic to the Metal Ages: Technical and Codified Practices. Session of the XIth Annual Meeting of the European Association of Archaeologists. BAR Int. Ser. 1758 Oxford.

Jalhay, E., 1944. O esconderijo pre-histórico de Pôrto do Concelho (Mação, Beira Baixa). Brotéria 38 (3), 263-277.

Kopytoff, I., 1986. The cultural biography of things: commoditization as process. In: Appadurai, A. (Ed.), The Social Life of Things: Commodities in Cultural Perspective. The Press Syndicate of the University of Cambridge, pp. 64-91.

Leitão, N.M., Lopes, J.M., 1985. Nótula sobre um achado arqueológico no lugar do Travasso, concelho da Mealhada. Instrumentos do Bronze (continuação). Pampilhosa. Uma Terra e um Povo. 4, 19-24.

Levy, J.E., 1981. Religious ritual and social stratification in prehistory societies: an example from Bronze Age Denmark. Hist. Relig. 21 (2), 172-188.

Lobato, M.J.F., 1992/1993. Os machados de bronze da Colecção do Museu Municipal Azuaga. Contributo para a paleometalurgia do Bronze no Norte de Portugal. Portugalia. XIII-XIV, 159-172.

Neiva, A.M.R., 2002. Portuguese granites associated with Sn-W and Au mineralizations. Bull. Geol. Soc. Finl. 74, 79-101.
Melo, A.Á., 2000. Armas , utensílios e esconderijos. Alguns aspectos da metalurgia do Bronze Final : o depósito do Casal dos Fiéis de Deus. Rev. Port. Arqueol. 3, $15-120$.

Montero-Ruiz, I., Rovira Llorens, S., Delibes De Castro, G., Fernández Manzano, J., Fernández-Posse, M.D., Herrán, J.I., Martín, C. Maicas, R., 2003. High leaded bronze in the Late Bronze Age metallurgy of the Iberian Peninsula. In: Associazione Italiana di Metallurgia (Ed.), Archaeometallurgy in Europe. Associazione Italiana di Metallurgia, Milan, pp. 1-8.

Moyler, S., 2008. Doing away with dichotomies? Comparative use-wear analysis of Early Bronze Age axes from Scotland. In: Hamon, C., Quilliec, B. (Eds.), Hoards From the Neolithic to the Metal Ages: Technical and Codified Practices. BAR Int. Ser. 1758, pp. 79-90.

Nebelski, L., 2000. Rent asunder: ritual violence in Late Bronze Age hoards. In: Pare, C.F.E. (Ed.), Metals Make the World Go Round. The Supply and Circulation of Metals in Bronze Age Europe. Oxbow Books, Oxford, pp. 160-175.

Osborne, R., 2004. Hoards, votives, offerings: the archaeology of the dedicated object World Archaeol. 36 (1), 1-10. http://dx.doi.org/10.1080/0043824042000192696.

Perea, A., 2008. Iberian Psycho. Deliberate destruction in Bronze Age gold hoards of the Iberian Peninsula. In: Hamon, C., Quilliec, B. (Eds.), Hoards From the Neolithic to the Metal Ages: Technical and Codified Practices. BAR Int. Ser. 1758, pp. 53-58.

Pereira, M.A.H., 1971. O esconderijo do bronze final de Coles de Samuel (Soure). Arqueol. e História. 3, 165-174.

Rovira Llorens, S., 2004. Tecnologia metalúrgica y cambio cultural en la prehistoria de la Península Ibérica. Norba. Revista de Historia. 17, 9-40.

Rovira Llorens, S., Ambert, P., 2002. Vasijas cerámicas para reducir minerales de cobre en la Península Ibérica y en la Francia Meridional. Trab. Prehist. 59, 89-105. http://dx doi.org/10.3989/tp.2002.v59.i1.212.

Rovira Llorens, S., Montero-Ruiz, I., 2013. Technological Development of Prehistoric Metallurgy. In: Burmeister, S., Hansen, S., Kunst, M., Müller-Scheeßel, N. (Eds.), Metal Matters. Innovative Technologies and Social Change in Prehistory and Antiquity. Leidorf, pp. 231-239.

Schiavon, N., Celauro, A., Manso, M., Brunetti, A., Susanna, F., 2013. Iron-age bronze statuettes in Southern Portugal: combining archaeological data with EDXRF and BSEM + EDS to assess provenance and production technology. Appl. Phys. A Mater. Sci. Process. 113, 865-875. http://dx.doi.org/10.1007/s00339-013-7747-7.

Scott, D.A., 1991. Metallography and Microstructure of Ancient and Historic Metals, Getty Conservation Institute in Association With Archetype Books. Tien Wah Press, Ltd., Singapore.

Silva, R.J.C., Figueiredo, E., Araújo, M.F., Pereira, F., Braz Fernandes, F.M., 2008. Microstructure interpretation of copper and bronze archaeological artefacts from Portugal. Mater. Sci. Forum 587-588, 365-369. http://dx.doi.org/10.4028/www.scientific.net/ MSF.587-588.365.

Soares, A.M.M., Cabral, J.M.P., 1993. Cronologia absoluta para o Calcolítico da Estremadura e do Sul de Portugal. Trab. Antropol. e Etnol. 33, 217-235.

Taylor, R.J., 1993. Hoards of the Bronze Age in Southern Britain. Analysis and Interpretation. BAR British Series 228 Oxford.

Tylecote, R.F., 1992. A History of Metallurgy. second ed. Maney Publishing, London.

Valério, P., Araújo, M.F., Senna-Martinez, J.C., Vaz, J.L.I., 2006. Caracterização química de produções metalúrgicas do Castro da Senhora da Guia de Baiões (Bronze Final). 0 Arqueólogo Port. IV 24, 289-319.

Valério, P., Araújo, M.F., Canha, A., 2007. EDXRF and micro-EDXRF studies of Late Bronze Age metallurgical productions from Canedotes (Portugal). Nucl. Instr. Methods Phys. Res. Sect. B Beam Interact. Mater. Atoms 263, 477-482. http://dx.doi.org/10.1016/j. nimb.2007.07.004

Valério, P., Silva, R.J.C., Araújo, M.F., Soares, A.M.M., Barros, L., 2012. A multianalytical approach to study the Phoenician bronze technology in the Iberian peninsula-a view from Quinta do Almaraz. Mater. Charact. 67, 74-82. http://dx.doi.org/10.1016/j. matchar.2012.02.020.

Valério, P., Silva, R.J.C., Soares, A.M.M., Araújo, M.F., Braz Fernandes, F.M., Silva, A.C., Berrocal-Rangel, L., 2010. Technological continuity in Early Iron Age bronze metallurgy at the South-Western Iberian Peninsula - a sight from Castro dos Ratinhos. J. Archaeol. Sci. 37, 1811-1819. http://dx.doi.org/10.1016/j.jas.2010.01.038.

Valério, P., Silva, R.J.C., Soares, A.M.M., Araujo, M.F., Goncalves, A.P., Soares, R.M., 2015 Combining X-ray based methods to study the protohistoric bronze technology in Western Iberia. Nucl. Inst. Methods Phys. Res. B 358, 117-123. http://dx.doi.org/10. 1016/j.nimb.2015.06.011.

Valério, P., Soares, A.A.M., Araújo, M.F., Silva, R.J.C., Santos, F.J.C., 2013. The distinctive grave goods from Palhais (Beja, Portugal). New insights into the metallurgical evolution under Orientalizing influence in the southwestern end of Iberia. Trab. Prehist. 70, 361-371. http://dx.doi.org/10.3989/tp.2013.12117.

Valério, P., Soares, A.M.M., Monteiro, M., Pereira, A. Araújo, M.F., Silva, R.C., 2016. A compositional and microstructural study of eighth-century BC bronzes from Moita da Ladra (Tagus Estuary): how did the spread of the Phoenician metallurgy take place in Western Iberia? Archaeometry http://dx.doi.org/10.1111/ arcm.12197 (in press).

Vasconcelos, J.L., 1919-20. Estudo sóbre a época do bronze em Portugal. Tesouro do Casa de Fiéis-de-Deus. O Archeólogo Português. I. 24, 193-195.

Vilaça, R., 2006. Depósitos de Bronze do Território Português Um debate em aberto. Separata de o Arqueólogo Português. O Arqueólogo Port. 24, 9-150.

Vilaça, R., 1997. Metalurgia do Bronze final da Beira Interior. Revisão dos dados à luz de novos resultados. Estudos Pré- históricos. 5, 123-154.

Vilaça, R., Almeida, S., Bottaini, C., Marques, J.N., Montero-Ruiz, I., 2012a. Metalurgia do Castro do Cabeço da Argemela (Fundão): formas, conteúdos, produções e contextos. In: Martins, C.M.B., Bettencourt, A.M.S., Martins, J.I.F.P., Carvalho, J. (Eds.) Povoamento e Exploração dos recursos mineiros na Europa Atlântica Ocidental. Ed. CITCEM - APEQ Braga, pp. 427-451. 
Vilaça, R., Bottaini, C., Montero-Ruiz, I., 2012b. O depósito do Cabeço de Maria Candal, Freixianda (Ourém, Portugal). O Arqueólogo Port. V 2, 297-353.

Wang, Q., Merkel, J.F., 2001. Studies on the redeposition of copper in Jin Bronzes from Tianma Qucun, Shanxi, China. Stud. Conserv. 46, 242-250. http://dx.doi.org/10. $2307 / 1506774$
Whitley, J., 2002. Objects with attitude: biographical facts and fallacies in the study of Late Bronze Age and Early Iron Age warrior graves. CAJ Camb. Archaeol. J. 12, 217-232. http://dx.doi.org/10.1017/S0959774302000112.

York, J., 2002. The life cycle of bronze age metalwork from the Thames. Oxf. J. Archaeol. 21, 77-92. http://dx.doi.org/10.1111/1468-0092.00150. 